\title{
Respons Adaptif Kambing Perah Sapera Dara Terhadap Stres Panas Akibat Perubahan Kuantitas Pakan
}

\author{
(ADAPTIVE RESPONSE OF YOUNG SAPERA DAIRY GOAT \\ ON HEAT STRESS DUE TO CHANGE IN FEED QUANTITIES)
}

\author{
Fitra Aji Pamungkas ${ }^{1,6}$, Bagus Priyo Purwanto ${ }^{2}$, Wasmen Manalu ${ }^{3}$, \\ Ahmad Yani ${ }^{4}$, Riasari Gail Sianturi ${ }^{5}$ \\ ${ }^{1}$ Program Studi Ilmu Produksi dan Teknologi Peternakan, \\ Sekolah Pascasarjana, Institut Pertanian Bogor \\ Jln Agathis, Kampus IPB, Dramaga Bogor, \\ Jawa Barat, Indonesia 16880 \\ ${ }^{2}$ Sekolah Vokasi IPB \\ ${ }^{3}$ Departemen Anatomi, Fisiologi, dan Farmakologi, \\ Fakultas Kedokteran Hewan, IPB \\ ${ }^{4}$ Departemen Ilmu Produksi dan Teknologi Peternakan, \\ Fakultas Peternakan, IPB \\ ${ }^{5}$ Balai Penelitian Ternak Ciawi, Bogor \\ ${ }^{6}$ Pusat Penelitian dan Pengembangan Peternakan, Bogor \\ Email: fitrap@yahoo.com
}

\begin{abstract}
This study aimed to evaluate the adaptive response of young sapera dairy goats on heat stress due to changes in feed quantities. Four young sapera dara dairy goats was kept in individual cages measuring 1.6 $\times 1.0 \mathrm{~m}^{2}$. Feeding in the form of concentrate and silage, respectively $800 \mathrm{~g} /$ day (A), $500 \mathrm{~g} /$ day (B), $200 \mathrm{~g} /$ day (C), and without feeding (D). The study design used Latin squares $4 \mathrm{x} 4$ with observed parameters including environmental conditions, physiological and haematological responses. The results showed that the air temperature, humidity, and wind speed in the cage were $20.94-31.59{ }^{\circ} \mathrm{C}, 47.19-99.20 \%$, and $1.81-2.02 \mathrm{~m} /$ sec, respectively. Physiological and haematological responses of the four groups indicated that skin temperature, respiratory rate, and haematological parameters did not show significant differences $(\mathrm{P}>0.05)$, while body and rectal temperature, and heart rate showed differences $(\mathrm{P}<0.05)$ only at several points of observation, especially between groups A and D. In general, the rectal temperature and heart rate of 38.5$39.3{ }^{\circ} \mathrm{C}$ and $72.0-99.5$ times per minute were still within the normal range. The physiological and haematological response values of group D that were lower than another groups indicated that reducing feed intake would reduce the metabolic heat generated in an effort to maintain the body's thermal balance and the adaptive response of goats. This indicates that the young sapera dairy goat has the adaptive ability to heat stress due to changes in feed quantity.
\end{abstract}

Keywords: Sapera dairy goat; heat stress; restrictly feeding; adaptive ability

\begin{abstract}
ABSTRAK
Penelitian bertujuan untuk mengevaluasi respon adaptif kambing perah sapera dara terhadap stres panas akibat perubahan kuantitas pakan. Empat ekor kambing perah sapera dara dipelihara pada kandang individu berukuran $1,6 \times 1,0 \mathrm{~m}^{2}$. Pemberian pakan berupa konsentrat dan silase masing-masing $800 \mathrm{~g} / \mathrm{hari}$ (A), $500 \mathrm{~g} / \mathrm{hari}$ (B), $200 \mathrm{~g} / \mathrm{hari}$ (C), dan tanpa pemberian (D). Rancangan penelitian menggunakan Bujur Sangkar Latin 4 x 4 dengan parameter yang diamati meliputi kondisi lingkungan, respons fisiologis dan hematologis. Hasil penelitian menunjukkan bahwa suhu udara, kelembapan, dan kecepatan angin di dalam kandang berturut-turut sebesar 20,94-31,59 ${ }^{\circ} \mathrm{C}, 47,19-99,20 \%$, dan 1,81-2,02 m/detik. Respons fisiologis dan hematologis dari keempat kelompok menunjukkan bahwa suhu kulit, frekuensi pernapasan, dan parameter hematologis secara statistika tidak menunjukkan perbedaan $(\mathrm{P}>0,05)$, sedangkan suhu tubuh, suhu rektal, dan denyut jantung menunjukkan perbedaan $(\mathrm{P}<0,05)$ hanya di beberapa titik
\end{abstract}


pengamatan terutama antara kelompok A dengan D. Secara umum, suhu rektal dan detak jantung berturut-turut sebesar $38,5-39,3^{\circ} \mathrm{C}$ dan $72,0-99,5$ kali per menit masih berada dalam kisaran normal. Nilai respons fisiologis dan hematologis kelompok D yang lebih rendah dari kelompok lainnya menunjukkan dengan pengurangan asupan pakan akan mengurangi panas metabolik yang terbentuk sebagai upaya untuk mempertahankan keseimbangan termal tubuh dan respons adaptif ternak. Hal ini menunjukkan bahwa kambing perah Sapera dara memiliki kemampuan adaptif terhadap stres panas akibat perubahan kuantitas pakan.

Kata-kata kunci: kambing sapera dara; stres panas; pembatasan pakan; kemampuan adaptasi

\section{PENDAHULUAN}

Kambing perah pada saat ini mempunyai prospek untuk dikembangkan dan bernilai ekonomis tinggi, yang terlihat dari produk susunya yang masih sangat eksklusif dengan khasiatnya dalam meningkatkan kesehatan tubuh, membantu dan mengatasi sejumlah penyakit, serta untuk bidang kosmetik sebagai bahan kecantikan. Salah satu jenis kambing perah yang mulai dikembangkan di Indonesia adalah kambing persilangan saanen dengan peranakan ettawah yang dinamakan kambing sapera. Di sisi lain, faktor penentu agar kambing perah dapat berproduksi optimal sesuai dengan kemampuan genetik yang dimilikinya ialah daya tahan kambing terhadap panas, terutama pada kambing dara yang akan memasuki masa produksi. Kambing perah dapat mengalami stres karena kondisi iklim daerah tropis yang terus mengalami perubahan serta penurunan kualitas dan kuantitas sumber pakan terutama di musim kemarau, hal ini ditandai dengan kondisi tidak nyaman yang dirasakan secara fisiologis oleh ternak (Sejian et al., 2010; Gupta et al., 2013; Silanikove dan Koluman, 2015).

Stres akibat peningkatan suhu atau kelembapan dapat mempengaruhi reproduksi ternak, seperti gangguan pada fungsi endometrium, ukuran folikel, kualitas oosit, dan perkembangan embrio (Wolfenson et al., 2000; Gendelman dan Roth, 2012; Silva et al., 2013), bahkan penurunan tingkat kebuntingan hingga 23\% (García et al., 2007). Begitu pula stres akibat penurunan kualitas dan kuantitas pakan mengakibatkan terjadinya ketidakseimbangan antara produksi dan pelepasan panas dalam tubuh sehingga berpengaruh terhadap fisiologis, metabolisme, hormonal, maupun sistem kekebalan tubuh (Gupta et al., 2013; Das et al., 2016). Lebih lanjut Naiddin et al., (2010) melaporkan bahwa pemberian kuantitas pakan dengan level yang berbeda menyebabkan adanya aktivitas metabolik dalam tubuh ternak yang berbeda pula, makin banyak jumlah pakan yang dikonsumsi menyebabkan peningkatan respons fisiologis ternak.

Respons fisiologis yang secara umum terjadi akibat stres, yaitu dalam upaya mempertahankan suhu tubuh dalam kisaran normal melalui peningkatan frekuensi pernapasan, suhu tubuh, keringat, dan konsumsi air, penurunan detak jantung dan asupan pakan (Mortola dan Frappell, 2000; Horowitz, 2002; Gupta et al., 2013; Caulfield et al., 2014). Selain itu, indikator utama respons imunitas ialah sistem hematologis, seperti sel darah putih, sel darah merah, maupun haemoglobin dilaporkan juga mengalami perubahan akibat stres (Das et al., 2016). Berdasarkan latar belakang tersebut, penelitian ini bertujuan untuk mengevaluasi perubahan fisiologis dan hematologis darah kambing perah sapera dara dalam kondisi iklim tertentu yang mengalami stres panas akibat pembatasan jumlah pakan.

\section{METODE PENELITIAN}

\section{Waktu dan Tempat}

Penelitian dilaksanakan pada Bulan Oktober 2019 bertempat di Unit Penelitian Kambing, Balai Penelitian Ternak Ciawi, Bogor yang terletak pada ketinggian 450 sampai 500 $\mathrm{m}$ dpl dengan potensi curah hujan antara 3500 sampai $4000 \mathrm{~mm}_{\text {tahun }}{ }^{-1}$. Penggunaan hewan coba telah mendapatkan persetujuan dari Komisi Kesejahteraan Hewan Coba Balitbangtan (KKHB), Kementerian Pertanian Republik Indonesia dengan nomor registrasi: Balitbangtan/Balitnak/Rm/04/2019.

\section{Materi Penelitian}

Materi yang digunakan dalam penelitian ini adalah empat ekor kambing perah sapera (saanen x peranakan ettawah) dara berumur 810 bulan dengan kisaran bobot badan $26-28 \mathrm{~kg}$ dalam kondisi sehat yang dipelihara pada kandang individu berukuran 1,6×1,0 $\mathrm{m}^{2}$. 
Kandang berada dalam gedung yang beratapkan asbes dengan kandang terbuat dari metal berlantai kayu dan tempat pakan terbuat dari kayu.

Pakan yang diberikan berupa konsentrat (C-Prolac $^{\circledR}$, PT. Citra Ina Feedmill, Jakarta, Indonesia) dan hijauan berupa rumput gajah cacahan (dipotong-potong) yang sudah dijadikan silase. Pemberian pakan berupa konsentrat dan silase masing-masing $800 \mathrm{~g} / \mathrm{hari}$ (A), $500 \mathrm{~g} / \mathrm{hari}$ (B), $200 \mathrm{~g} /$ hari (C), dan tanpa pemberian (D). Acuan jumlah pemberian pakan A berdasarkan hasil pra-penelitian yang dilakukan pada kambing sapera dara.

\section{Pemeliharaan Ternak}

Kambing dipelihara selama 12 hari dengan jadwal pemberian pakan sebanyak dua kali sehari, yaitu pukul 07.00 dan 15.00 WIB dengan pengukuran tingkat konsumsi pakan di pagi hari. Pemberian air minum dilakukan selama dua jam dari jadwal pemberian pakan dengan memakai ember tempat minum yang disediakan pada setiap kandang. Jumlah pakan yang diberikan dan waktu pengukuran parameter penelitian disajikan pada Gambar 1 .

\section{Parameter Pengamatan}

Parameter yang diamati pada penelitian ialah kondisi lingkungan, respons fisiologis dan hematologis kambing perah. Data diperoleh dengan mengukur parameter kondisi lingkungan dengan selang waktu pengukuran setiap 30 menit, parameter respons fisiologis mulai pukul 06:00-18:00 WIB dengan selang waktu pengukuran setiap dua jam, sedangkan pengambilan sampel darah untuk pengukuran parameter hematologis hanya dilakukan pada awal dan akhir setiap hari pengukuran (pukul 06:00 dan 18:00 WIB).

\section{Kondisi Lingkungan}

Pengamatan kondisi lingkungan meliputi kondisi mikroklimat yang terdiri atas suhu udara, kelembapan relatif, dan kecepatan angin di lokasi penelitian. Suhu udara dan kelembapan relatif diukur dengan temperature and humidity datalogger ( Extech Tipe $42280^{\circledR}$, Extech FLIR Commercial Systems Inc, USA), sedangkan kecepatan angin diukur dalam kandang dengan menggunakan anemometer digital (Benetech GM816 ${ }^{\circledR}$, Benetech Inc, USA).

\section{Respons Fisiologis}

Parameter respons fisiologis yang diamati meliputi suhu permukaan kulit (Ts), suhu rektal (Tr), suhu tubuh (Tb), detak jantung $(\mathrm{Hr})$, dan frekuensi respirasi (Rr). Suhu rektal (Tr) diukur dengan memasukkan termometer rektal digital (Omron model MC-245 ${ }^{\circledR}$, Omron healthcare Co.

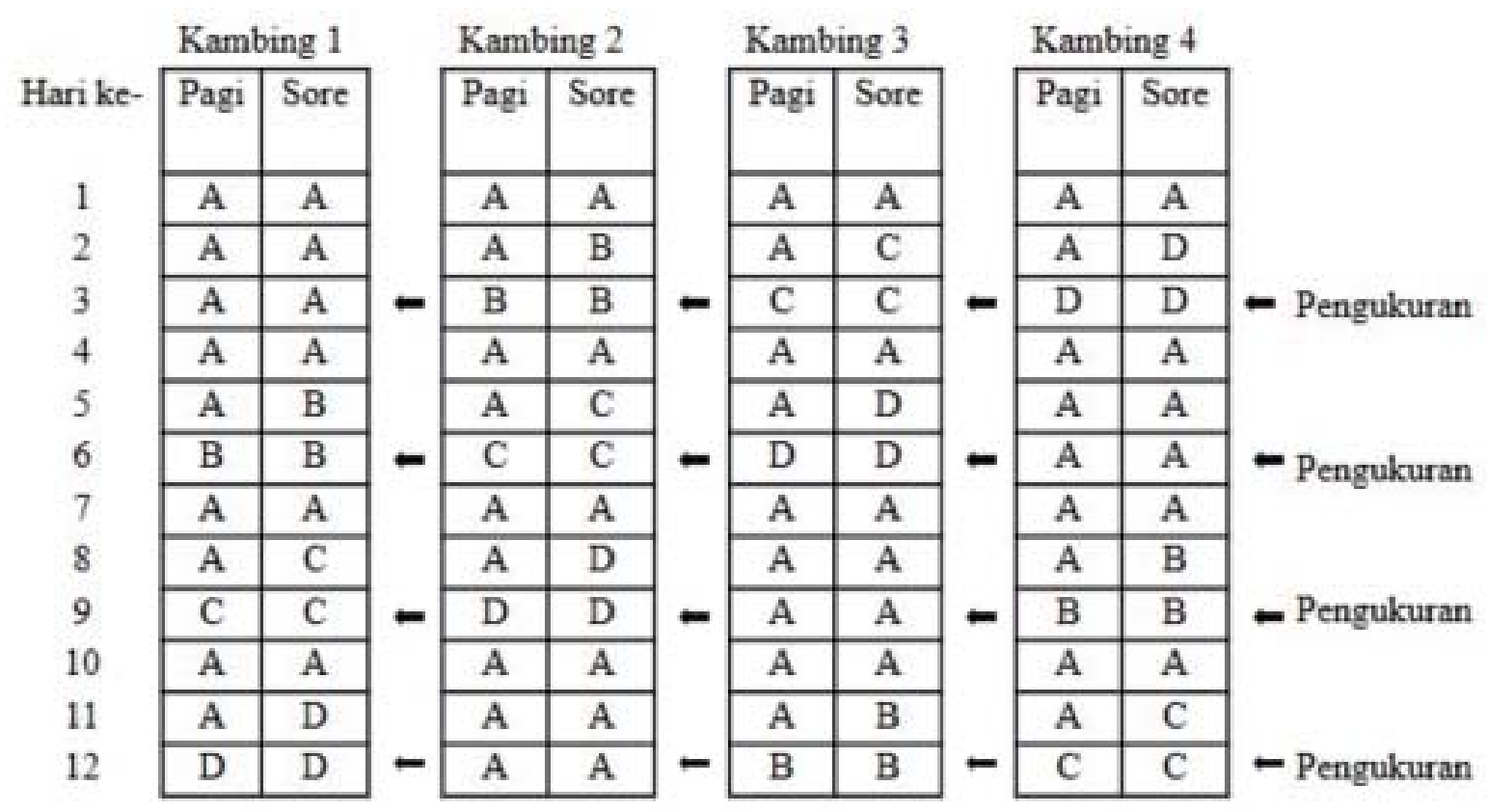

Gambar 1. Jadwal pemberian pakan dan waktu pengukuran parameter selama kegiatan penelitian. Pemberian pakan berupa konsentrat dan silase masing-masing 800 g/hari (A), 500 g/ hari (B), $200 \mathrm{~g} /$ hari (C), dan tanpa pemberian (D). 
Ltd., Kyoto, Jepang) ke dalam rektal sedalam \pm $5 \mathrm{~cm}$. Suhu permukaan kulit (Ts) diukur dengan termometer pengukur suhu kulit digital (Omron model MC-720 ${ }^{\circledR}$, Omron Healthcare Co. Ltd., Kyoto, Jepang) di empat titik lokasi pengukuran, yaitu punggung (W), dada (X), tungkai atas (Y), dan tungkai bawah (Z). Rataan suhu permukaaan kulit dihitung berdasarkan modifikasi rumus (McLean et al., 1983) sebagai berikut:

$\mathrm{Ts}_{\mathrm{s}}=0,25(\mathrm{~W}+\mathrm{X})+0,32 \mathrm{Y}+0,18 \mathrm{Z}$

Suhu tubuh ( $\mathrm{Tb})$ dihitung dari suhu permukaan kulit (Ts) dan menjumlahkan dengan suhu rektal (Tr) menurut (McLean et al., 1983). Suhu tubuh (Tb) dihitung dengan rumus :

$\mathrm{Tb}=0,86 \mathrm{Tr}+0,14 \mathrm{Ts}$

Detak jantung ( $\mathrm{Hr}$ ) diukur dengan menempelkan stetoskop di belakang prosesus olekranon tulang ulna pada dada sebelah kiri selama satu menit. Frekuensi respirasi ( $\mathrm{Rr}$ ) diukur setelah pengukuran detak jantung dengan cara menempelkan stetoskop di dada untuk menghitung inspirasi dan ekspirasi pernapasan selama satu menit.

\section{Parameter Hematologis}

Koleksi darah dilakukan pada posisi ternak berdiri dan dalam keadaan tenang. Darah diambil sebanyak $0,5 \mathrm{~mL}$ melalui vena jugularis dengan terlebih dahulu membersihkan daerah leher dengan kapas beralkohol 70\% supaya area vena terlihat jelas, lalu membendung pembuluh darah (vena jugularis) dengan ibu jari sehingga terlihat vena menggelembung. Jarum suntik steril yang digunakan berukuran $20 \mathrm{G}$ dengan kedalaman jarum satu inchi dimasukkan ke dalam vena jugularis, pada saat darah terlihat keluar, kemudian jarum dihubungkan dengan tabung vacutainer, posisi pengambilan darah dengan sudut $45^{\circ} \mathrm{C}$. Setelah pengambilan darah, kambing dikembalikan ke dalam kandang individu, dengan memastikan terlebih dahulu bahwa tidak terjadi pendarahan atau pembengkakan yang berlebihan.

Setelah koleksi, tabung disimpan di dalam kotak yang berisi es lalu dibawa ke laboratorium untuk dianalisis. Profil hematologi dianalisis menggunakan alat (Vetscan ${ }^{\circledR}$ HM5 Hematology Analyzer, Abaxis. Inc, USA) dengan parameter yang diamati adalah: jumlah sel darah putih (WBC), sel darah merah (RBC), limfosit (LYM), monosit (MON), neutrofil (NEU), haemoglobin (HGB), hematokrit (HCT), volume rata-rata sel darah merah (MCV), rata-rata haemoglobin dalam sel $(\mathrm{MCH})$, konsentrasi rata-rata haemoglobin dalam sel (MCHC), variasi ukuran eritrosit (RDW), dan trombosit (PLT).

\section{Analisis Data}

Terdapat dua faktor dalam percobaan ini, yaitu individu kambing dan perlakuan sehingga digunakan Rancangan Bujur Sangkar Latin 4 $\mathrm{x}$ 4. Data yang terkumpul dianalisis menggunakan prosedur MIXED dari SAS (V. 9.1; SAS Institute Inc., Cary, NC, USA) dengan tingkat signifikansi ditetapkan sebesar 0,05.

\section{HASIL DAN PEMBAHASAN}

\section{Kondisi Lingkungan}

Kondisi lingkungan, baik suhu udara, kelembapan, maupun kecepatan angin di dalam kandang selama penelitian disajikan pada Gambar 2. Suhu udara terendah di dalam kandang dicapai pada pukul $06.00\left(20,94^{\circ} \mathrm{C}\right)$, sedangkan suhu udara tertinggi dicapai pada pukul $11.30\left(31,59^{\circ} \mathrm{C}\right)$. Berbeda halnya dari kelembapan di dalam kandang yang mencapai nilai tertinggi pada pukul $06.00(99,20 \%)$, namun mencapai nilai terendah pada pukul $12.00(47,19 \%)$. Hasil penelitian menunjukkan bahwa suhu udara dan kelembapan di dalam kandang mengalami fluktuasi di sepanjang hari pengamatan. Fluktuasi suhu udara dan kelembapan dipengaruhi oleh radiasi matahari, produksi panas tubuh ternak, tinggi, luas, bahan atap, serta bukaan ventilasi kandang yang kurang tepat (Yani et al. 2007; Widyarti dan Oktavia, 2011).

Kecepatan angin di lokasi penelitian berkisar antara 1,81-2,02 m/detik. Misra dan Puneet (2009) melaporkan bahwa zona nyaman untuk kambing berada pada lingkungan dengan kecepatan angin 1,38-2,22 m/detik. Begitupula Lee dan Keala (2005) melaporkan bahwa kecepatan angin dalam kandang sebesar 1,12$1,30 \mathrm{~m} /$ detik dapat membantu ternak untuk mengatasi cekaman panas. Walaupun demikian, untuk menurunkan suhu dan kelembapan udara di dalam kandang agar tetap berada pada zona nyaman dapat dilakukan dengan menambah luas bukaan ventilasi yang berperan dalam pola aliran dan distribusi udara dalam kandang. Yani et al. (2007) melaporkan bahwa pengaturan sistem ventilasi dapat dilakukan sebagai salah satu upaya untuk menurunkan suhu dan kelembapan udara di dalam kandang agar terjadi pertukaran udara 
di dalam dan luar kandang dengan baik sehingga panas dalam kandang dapat diminimalisir.

\section{Respons Fisiologis}

Hasil pengukuran tingkat konsumsi pakan menunjukkan bahwa konsumsi konsentrat dan

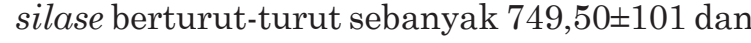
$619,25 \pm 121,76 \mathrm{~g} /$ hari untuk kelompok A, $483,75 \pm 32,50$ dan $428,50 \pm 89,40 \mathrm{~g} /$ hari (B), $200 \pm 0,00$ dan $187,50 \pm 25,00 \mathrm{~g} /$ hari (C), serta tanpa pemberian pakan (D). Hasil ini menunjukkan bahwa kambing sapera dara hampir mengkonsumsi seluruh konsentrat maupun silase yang diberikan. Hal ini sejalan dengan yang dilaporkan Aryanto et al. (2013) bahwa pakan yang selalu tersedia menyebabkan aktivitas rumen bertambah sehingga ternak akan menambah konsumsi pakannya.

Kondisi fisiologis kambing sapera dara selama penelitian disajikan pada Tabel 1. Suhu kulit keempat kelompok secara statistika tidak menunjukkan perbedaan yang nyata $(\mathrm{P}>0,05)$ di sepanjang hari pengamatan. Suhu kulit menunjukkan grafik berbentuk kurva sejalan dengan peningkatan atau penurunan suhu udara di dalam kandang. Suhu kulit pada pukul 06:00 diperoleh sebesar $27,1-27,9^{\circ} \mathrm{C}$, lalu mengalami peningkatan hingga pukul $14.00\left(32,3-32,7^{\circ} \mathrm{C}\right)$, selanjutnya terjadi penurunan hingga pukul $18.00\left(29,7-31,1^{\circ} \mathrm{C}\right)$. Hasil ini menunjukkan bahwa penurunan jumlah pakan tidak memberikan pengaruh pada suhu kulit, yang menandakan bahwa kambing sapera dara dapat menjaga suhu kulit tetap berada dalam kisaran normal. Menurut Mengistu et al. (2007), kambing mempertahankan suhu tubuhnya dalam kondisi normal melalui mekanisme termoregulasi, yaitu proses menjaga keseimbangan panas antara produksi dengan pelepasan panas. Hasil serupa dilaporkan oleh Shilja et al. (2016) bahwa penurunan jumlah pakan tidak menunjukkan perubahan suhu kulit di beberapa bagian tubuh (kepala, skrotum, maupun perut), peningkatan suhu kulit terjadi karena ternak terpapar radiasi matahari dan ketidakmampuannya untuk mempertahankan homeostasis selama proses mekanisme termoregulasi. Hasil penelitian ini berbeda dari yang dilaporkan oleh Darcan dan Güney (2008) pada kambing perah persilangan (German Fawn $\mathrm{x}$ kambing lokal) yang berada di Turki, diperoleh bahwa suhu kulit pada pukul 06:00, 12:00, 18:00, dan 24:00 berturut-turut adalah sebesar $28,59,32,68,34,71$, dan $29,48^{\circ} \mathrm{C}$, yaitu penurunan suhu kulit baru terjadi setelah pukul 18.00. Hal ini terjadi karena perbedaan iklim di lokasi penelitian, di mana pada daerah yang beriklim mediterania seperti Turki memiliki

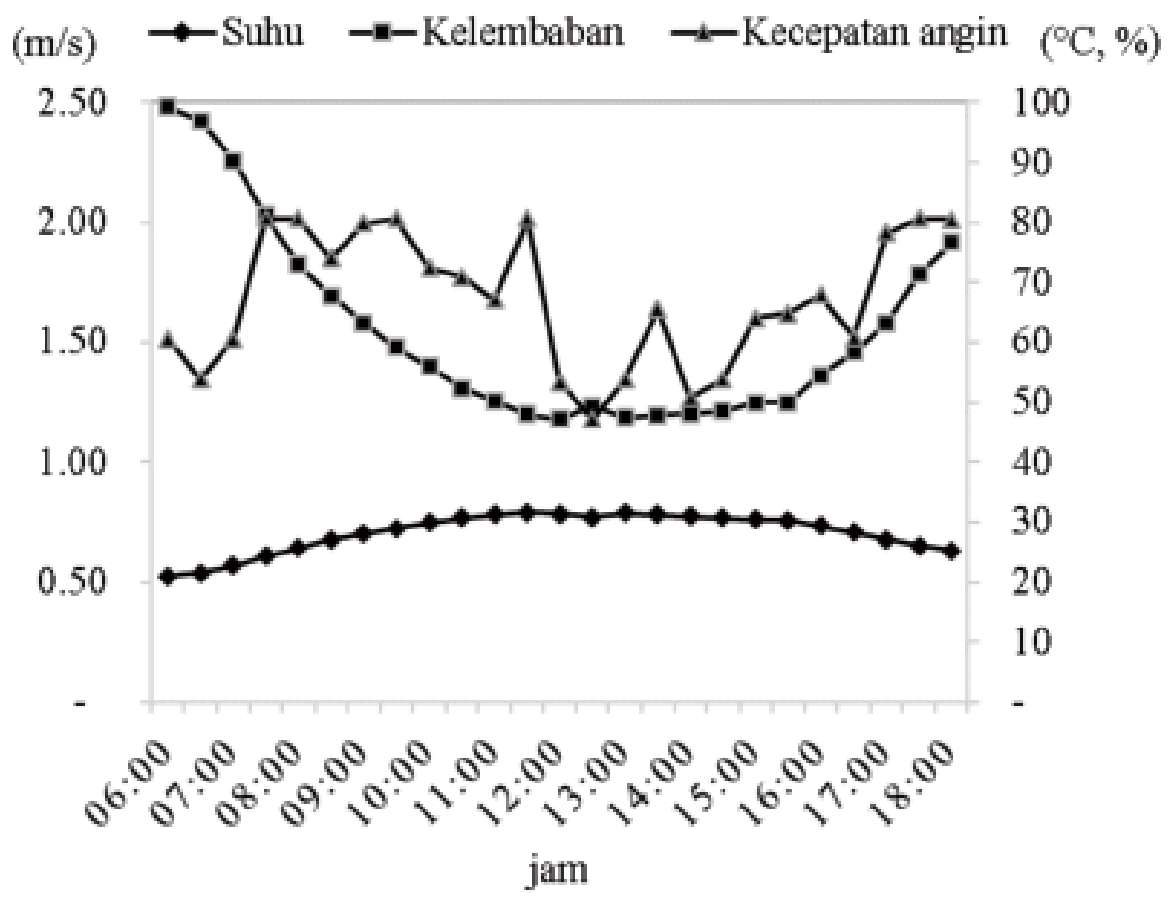

Gambar 2. Kondisi lingkungan kandang selama penelitian respons adaptif kambing perah sapera dara terhadap stres panas 
Tabel 1. Kondisi fisiologis kambing sapera dara selama penelitian (rerata $\pm \mathrm{SD}, \mathrm{n}=4$ )

\begin{tabular}{|c|c|c|c|c|c|c|c|c|}
\hline \multirow{2}{*}{ Parameter } & \multirow{2}{*}{ Kelompok } & \multicolumn{7}{|c|}{ Waktu pengamatan (pukul) } \\
\hline & & 6:00 & 8:00 & $10: 00$ & $12: 00$ & $14: 00$ & $16: 00$ & $18: 00$ \\
\hline $\begin{array}{l}\text { suhu kulit } \\
\left({ }^{\circ} \mathrm{C}\right)\end{array}$ & $\begin{array}{l}\text { A } \\
\text { B } \\
\text { C } \\
\text { D }\end{array}$ & $\begin{array}{l}27,9 \pm 2,4^{\mathrm{a}} \\
27,5 \pm 1,9^{\mathrm{a}} \\
27,7 \pm 1,6^{\mathrm{a}} \\
27,1 \pm 0,8^{\mathrm{a}}\end{array}$ & $\begin{array}{l}32,5 \pm 0,4^{\mathrm{a}} \\
31,8 \pm 1,8^{\mathrm{a}} \\
31,0 \pm 1,6^{\mathrm{a}} \\
30,9 \pm 1,2^{\mathrm{a}}\end{array}$ & $\begin{array}{l}33,5 \pm 0,5^{\mathrm{a}} \\
32,8 \pm 0,9^{\mathrm{a}} \\
32,2 \pm 1,3^{\mathrm{a}} \\
32,2 \pm 0,9^{\mathrm{a}}\end{array}$ & $\begin{array}{l}32,5 \pm 1,3^{\mathrm{a}} \\
32,1 \pm 0,8^{\mathrm{a}} \\
32,3 \pm 1,2^{\mathrm{a}} \\
32,6 \pm 1,5^{\mathrm{a}}\end{array}$ & $\begin{array}{l}32,7 \pm 0,9^{\mathrm{a}} \\
32,7 \pm 1,2^{\mathrm{a}} \\
32,3 \pm 1,6^{\mathrm{a}} \\
32,4 \pm 1,5^{\mathrm{a}}\end{array}$ & $\begin{array}{c}31,5 \pm 0,97^{\mathrm{a}} \\
31,4 \pm 1,0^{\mathrm{a}} \\
31,2 \pm 2,0^{\mathrm{a}} \\
31,0 \pm 1,1^{\mathrm{a}}\end{array}$ & $\begin{array}{l}31,1 \pm 1,3^{\mathrm{a}} \\
30,5 \pm 1,2^{\mathrm{a}} \\
29,9 \pm 1,6^{\mathrm{a}} \\
29,7 \pm 1,5^{\mathrm{a}}\end{array}$ \\
\hline $\begin{array}{l}\text { suhu tubuh } \\
\left({ }^{\circ} \mathrm{C}\right)\end{array}$ & $\begin{array}{l}\mathrm{A} \\
\mathrm{B} \\
\mathrm{C} \\
\mathrm{D}\end{array}$ & $\begin{array}{l}37,1 \pm 0,6^{\mathrm{a}} \\
37,0 \pm 0,3^{\mathrm{a}} \\
37,0 \pm 0,3^{\mathrm{a}} \\
36,9 \pm 0,1^{\mathrm{a}}\end{array}$ & $\begin{array}{l}37,8 \pm 0,2^{\mathrm{a}} \\
37,8 \pm 0,2^{\mathrm{a}} \\
37,6 \pm 0,3^{\mathrm{a}} \\
37,6 \pm 0,3^{\mathrm{a}}\end{array}$ & $\begin{array}{c}38,1 \pm 0,2^{\mathrm{a}} \\
38,0 \pm 0,2^{\text {ab }} \\
37,8 \pm 0,2^{\text {ab }} \\
37,7 \pm 0,3^{\text {b }}\end{array}$ & $\begin{array}{l}38,2 \pm 0,2^{\mathrm{a}} \\
38,0 \pm 0,2^{\mathrm{a}} \\
37,8 \pm 0,4^{\mathrm{a}} \\
37,8 \pm 0,3^{\mathrm{a}}\end{array}$ & $\begin{array}{l}38,3 \pm 0,2^{\text {a }} \\
38,2 \pm 0,2^{\text {a }} \\
37,9 \pm 0,3^{\text {a }} \\
37,9 \pm 0,2^{\text {a }}\end{array}$ & $\begin{array}{l}38,2 \pm 0,2^{\mathrm{a}} \\
38,1 \pm 0,2^{\mathrm{a}} \\
38,0 \pm 0,5^{\mathrm{a}} \\
38,0 \pm 0,3^{\mathrm{a}}\end{array}$ & $\begin{array}{r}38,1 \pm 0,2^{\mathrm{a}} \\
37,8 \pm 0,2^{\text {ab }} \\
37,7 \pm 0,4^{\mathrm{b}} \\
37,6 \pm 0,2^{\mathrm{b}}\end{array}$ \\
\hline $\begin{array}{l}\text { suhu rektal } \\
\left({ }^{\circ} \mathrm{C}\right)\end{array}$ & $\begin{array}{l}\text { A } \\
\text { B } \\
\text { C } \\
\text { D }\end{array}$ & $\begin{array}{l}38,6 \pm 0,3^{\mathrm{a}} \\
38,6 \pm 0,2^{\mathrm{a}} \\
38,6 \pm 0,2^{\mathrm{a}} \\
38,5 \pm 0,1^{\mathrm{a}}\end{array}$ & $\begin{array}{l}38,7 \pm 0,2^{\mathrm{a}} \\
38,7 \pm 0,1^{\mathrm{a}} \\
38,7 \pm 0,2^{\mathrm{a}} \\
38,7 \pm 0,3^{\mathrm{a}}\end{array}$ & $\begin{array}{l}38,8 \pm 0,2^{\mathrm{a}} \\
38,9 \pm 0,1^{\mathrm{a}} \\
38,7 \pm 0,1^{\mathrm{a}} \\
38,6 \pm 0,3^{\mathrm{a}}\end{array}$ & $\begin{array}{l}39,1 \pm 0,2^{\mathrm{a}} \\
39,0 \pm 0,1^{\mathrm{a}} \\
38,7 \pm 0,3^{\mathrm{b}} \\
38,7 \pm 0,1^{\mathrm{b}}\end{array}$ & $\begin{array}{c}39,2 \pm 0,1^{\mathrm{a}} \\
39,1 \pm 0,1^{\text {ab }} \\
38,9 \pm 0,2^{\mathrm{b}} \\
38,8 \pm 0,2^{\mathrm{b}}\end{array}$ & $\begin{array}{l}39,3 \pm 0,1^{\text {a }} \\
39,3 \pm 0,2^{\text {a }} \\
39,1 \pm 0,4^{\text {a }} \\
39,1 \pm 0,3^{\text {a }}\end{array}$ & $\begin{array}{r}39,3 \pm 0,1^{\mathrm{a}} \\
39,0 \pm 0,1^{\text {ab }} \\
38,9 \pm 0,3^{\mathrm{b}} \\
38,9 \pm 0,1^{\mathrm{b}}\end{array}$ \\
\hline $\begin{array}{l}\text { detak jantung } \\
\text { (kali/menit) }\end{array}$ & $\begin{array}{l}\text { A } \\
\text { B } \\
\text { C } \\
\text { D }\end{array}$ & $\begin{array}{c}88,5 \pm 3,4^{\mathrm{a}} \\
87,5 \pm 1,9^{\mathrm{a}} \\
85,5 \pm 12,6^{\mathrm{a}} \\
79,0 \pm 9,4^{\mathrm{a}}\end{array}$ & $\begin{array}{l}99,5 \pm 3,4^{\mathrm{a}} \\
98,5 \pm 4,4^{\mathrm{a}} \\
91,0 \pm 8,4^{\mathrm{a}} \\
76,5 \pm 6,6^{\mathrm{b}}\end{array}$ & $\begin{array}{l}97,0 \pm 5,0^{\mathrm{a}} \\
96,5 \pm 5,7^{\mathrm{a}} \\
85,5 \pm 7,7^{\mathrm{b}} \\
73,5 \pm 8,9^{\mathrm{c}}\end{array}$ & $\begin{array}{c}97,0 \pm 13,7^{\mathrm{a}} \\
94,5 \pm 4,7^{\mathrm{a}} \\
81,0 \pm 10,5^{\mathrm{ab}} \\
75,5 \pm 13,1^{\mathrm{b}}\end{array}$ & $\begin{array}{c}92,5 \pm 7,5^{\mathrm{a}} \\
89,0 \pm 6,8^{\mathrm{ab}} \\
79,0 \pm 9,0^{\mathrm{bc}} \\
73,5 \pm 9,3^{\mathrm{c}}\end{array}$ & $\begin{array}{c}99,0 \pm 5,3^{\mathrm{a}} \\
96,0 \pm 5,2^{\mathrm{a}} \\
87,5 \pm 16,1^{\mathrm{a}} \\
82,0 \pm 24,5^{\mathrm{a}}\end{array}$ & $\begin{array}{r}95,0 \pm 6.2^{\mathrm{a}} \\
92,5 \pm 3,4^{\mathrm{a}} \\
74,0 \pm 9,4^{\mathrm{b}} \\
72,0 \pm 10,6^{\mathrm{b}}\end{array}$ \\
\hline $\begin{array}{l}\text { frekuensi } \\
\text { pernapasan } \\
\text { (kali/menit) }\end{array}$ & $\begin{array}{l}\text { A } \\
\text { B } \\
\text { C } \\
\text { D }\end{array}$ & $\begin{array}{c}39,0 \pm 9,3^{\mathrm{a}} \\
33,5 \pm 11,3^{\mathrm{a}} \\
33,0 \pm 11,0^{\mathrm{a}} \\
29,0 \pm 9,6^{\mathrm{a}}\end{array}$ & $\begin{array}{l}40,0 \pm 8,2^{\mathrm{a}} \\
39,5 \pm 14,1^{\mathrm{a}} \\
39,0 \pm 12,8^{\mathrm{a}} \\
37,5 \pm 11,7^{\mathrm{a}}\end{array}$ & $\begin{array}{c}50,5 \pm 23,2^{\mathrm{a}} \\
48,0 \pm 15,1^{\mathrm{a}} \\
44,5 \pm 10,1^{\mathrm{a}} \\
42,5 \pm 9,6^{\mathrm{a}}\end{array}$ & $\begin{array}{c}66,0 \pm 27,9^{\mathrm{a}} \\
63,5 \pm 25,1^{\mathrm{a}} \\
53,5 \pm 28,2^{\mathrm{a}} \\
35,5 \pm 7,5^{\mathrm{a}}\end{array}$ & $\begin{array}{c}63,5 \pm 33,9^{\mathrm{a}} \\
51,5 \pm 27,9^{\mathrm{a}} \\
42,5 \pm 10,9^{\mathrm{a}} \\
31,5 \pm 7,7^{\mathrm{a}}\end{array}$ & $\begin{array}{l}63,0 \pm 33,2^{\mathrm{a}} \\
65,0 \pm 38,7^{\mathrm{a}} \\
49,5 \pm 16,5^{\mathrm{a}} \\
32,5 \pm 8,5^{\mathrm{a}}\end{array}$ & $\begin{array}{c}46,5 \pm 33,0^{\mathrm{a}} \\
43,0 \pm 18,7^{\mathrm{a}} \\
37,5 \pm 9,6^{\mathrm{a}} \\
29,5 \pm 7,7^{\mathrm{a}}\end{array}$ \\
\hline
\end{tabular}

Keterangan: Huruf superskrip yang berbeda pada kolom yang sama untuk setiap parameter menunjukkan perbedaan yang nyata $(\mathrm{P}<0,05)$

Perlakuan pemberian pakan berupa konsentrat dan silase masing-masing $800 \mathrm{~g} / \mathrm{hari}$ (A), $500 \mathrm{~g} /$ hari (B), $200 \mathrm{~g} /$ hari (C), dan tanpa pemberian (D).

suhu udara yang lebih tinggi dengan durasi yang lebih lama, berbeda dari daerah yang beriklim tropis, seperti Indonesia.

Suhu tubuh keempat kelompok kambing percobaan secara statistika menunjukkan perbedaan nyata $(\mathrm{P}<0,05)$ yang terjadi pada pengamatan pukul 10:00 dan 18:00 (setelah tiga jam pemberian pakan). Kelompok D memiliki suhu tubuh yang lebih rendah dibandingkan kelompok A. Hasil ini sesuai dengan yang dilaporkan oleh Sejian et al. (2018) dan Pragna et al. (2018) bahwa pakan merupakan sumber utama produksi panas sehingga dengan pengurangan asupan pakan akan mengurangi panas metabolik yang terbentuk dan penurunan suhu tubuh sebagai respons adaptif ternak. Lebih lanjut McManus et al. (2009) melaporkan bahwa penurunan asupan pakan dapat memperlambat metabolisme basal yang dapat menyebabkan hipofungsi kelenjar tiroid sehingga mencegah penambahan produksi panas metabolik. Hasil penelitian ini berbeda dari yang dilaporkan oleh Montanholi et al. (2008) pada sapi perah, yaitu proses produksi panas tubuh terjadi dua jam setelah pemberian pakan. Menurut Refinetti (2010), perbedaan waktu produksi panas tubuh kemungkinan disebabkan oleh kelembapan termal dan ukurun tubuh ternak.

Suhu rektal merupakan parameter yang sering digunakan untuk menggambarkan suhu tubuh meskipun adanya variasi suhu yang cukup besar di berbagai bagian tubuh pada waktu yang berbeda (Otoikhian et al., 2009). Suhu rektal juga telah terbukti digunakan sebagai indikator yang baik akan kejadian stres panas yang ditimbulkan oleh suhu lingkungan (Daramola dan Adeloye, 2009). Suhu rektal keempat kelompok kambing percobaan di sepanjang hari pengamatan berkisar antara $38,5-39,3^{\circ} \mathrm{C}$. Nilai suhu rektal yang diperoleh dalam penelitian ini masih berada pada kisaran normal, yaitu berkisar antara $38,5-40,0^{\circ} \mathrm{C}$ (Ayo, 1998). Suhu rektal secara statistika 
Tabel 2. Kondisi hematologis kambing sapera dara selama penelitian (rerata $\pm \mathrm{SD}, \mathrm{n}=4$ )

\begin{tabular}{|c|c|c|c|c|c|}
\hline \multirow{2}{*}{ Parameter } & \multirow{2}{*}{$\begin{array}{c}\text { Waktu } \\
\text { pengamatan } \\
\text { (Pukul) }\end{array}$} & \multicolumn{4}{|c|}{ Kelompok } \\
\hline & & $\mathrm{A}$ & B & $\mathrm{C}$ & $\mathrm{D}$ \\
\hline \multirow[t]{2}{*}{$\operatorname{RBC}\left(10^{6} / \mu \mathrm{L}\right)$} & 06:00 & $15,58 \pm 0,42^{\mathrm{a}}$ & $14,03 \pm 0,56^{\mathrm{a}}$ & $14,78 \pm 2,29^{\mathrm{a}}$ & $15,23 \pm 0,29^{a}$ \\
\hline & $18: 00$ & $15,38 \pm 0,79^{\mathrm{a}}$ & $14,39 \pm 1,42^{\mathrm{a}}$ & $14,83 \pm 1,25^{\mathrm{a}}$ & $14,90 \pm 0,80^{\mathrm{a}}$ \\
\hline \multirow[t]{2}{*}{$\mathrm{Hb}(\mathrm{g} / \mathrm{dL})$} & 06:00 & $9,45 \pm 0,35^{\mathrm{a}}$ & $8,90 \pm 0,53^{\mathrm{a}}$ & $9,55 \pm 0,34^{\mathrm{a}}$ & $9,28 \pm 0,46^{\mathrm{a}}$ \\
\hline & $18: 00$ & $9,35 \pm 1,02^{\mathrm{a}}$ & $8,73 \pm 0,45^{\mathrm{a}}$ & $8,95 \pm 0,26^{\mathrm{a}}$ & $9,03 \pm 0,34^{\mathrm{a}}$ \\
\hline \multirow[t]{2}{*}{ HCT (\%) } & 06:00 & $24,94 \pm 0,87^{\mathrm{a}}$ & $21,93 \pm 1,75^{\mathrm{a}}$ & $23,42 \pm 3,46^{\mathrm{a}}$ & $24,26 \pm 0,54^{\mathrm{a}}$ \\
\hline & $18: 00$ & $24,63 \pm 1,99^{\mathrm{a}}$ & $22,78 \pm 2,76^{\mathrm{a}}$ & $23,61 \pm 1,55^{\mathrm{a}}$ & $23,67 \pm 0,81^{\mathrm{a}}$ \\
\hline \multirow[t]{2}{*}{ MCV (fl) } & 06:00 & $16,25 \pm 0,50^{\mathrm{a}}$ & $15,67 \pm 1,15^{\mathrm{a}}$ & $15,75 \pm 0,50^{\mathrm{a}}$ & $16,00 \pm 0,82^{\mathrm{a}}$ \\
\hline & $18: 00$ & $16,00 \pm 0,82^{\mathrm{a}}$ & $15,75 \pm 0,96^{\mathrm{a}}$ & $16,00 \pm 0,00^{\mathrm{a}}$ & $16,00 \pm 0,00^{\mathrm{a}}$ \\
\hline \multirow[t]{2}{*}{ MCH (pg) } & 06:00 & $6,05 \pm 0,17^{\mathrm{a}}$ & $6,37 \pm 0,55^{\mathrm{a}}$ & $6,58 \pm 1,06^{\mathrm{a}}$ & $6,10 \pm 0,37^{\mathrm{a}}$ \\
\hline & $18: 00$ & $6,08 \pm 0,40^{\mathrm{a}}$ & $6,10 \pm 0,37^{\mathrm{a}}$ & $6,05 \pm 0,37^{\mathrm{a}}$ & $6,08 \pm 0,26^{\mathrm{a}}$ \\
\hline \multirow[t]{2}{*}{$\mathrm{MCHC}(\mathrm{g} / \mathrm{dL})$} & 06:00 & $37,88 \pm 1,02^{\mathrm{a}}$ & $40,70 \pm 4,33^{\mathrm{a}}$ & $41,38 \pm 5,99^{a}$ & $38,30 \pm 1,75^{\mathrm{a}}$ \\
\hline & $18: 00$ & $37,93 \pm 1,91^{\mathrm{a}}$ & $38,50 \pm 2,84^{\mathrm{a}}$ & $38,05 \pm 1,76^{\mathrm{a}}$ & $38,08 \pm 1,40^{\mathrm{a}}$ \\
\hline \multirow[t]{2}{*}{ RDWC (\%) } & 06:00 & $35,30 \pm 0,46^{\mathrm{a}}$ & $34,13 \pm 0,46^{\mathrm{a}}$ & $35,90 \pm 2,55^{\mathrm{a}}$ & $35,98 \pm 1,75^{\mathrm{a}}$ \\
\hline & $18: 00$ & $35,48 \pm 1,40^{\mathrm{a}}$ & $35,20 \pm 2,17^{\mathrm{a}}$ & $35,85 \pm 2,33^{\mathrm{a}}$ & $35,35 \pm 1,91^{\mathrm{a}}$ \\
\hline \multirow[t]{2}{*}{$\mathrm{WBC}\left(10^{3} / \mu \mathrm{L}\right)$} & 06:00 & $17,89 \pm 2,15^{\mathrm{a}}$ & $15,81 \pm 1,87^{a}$ & $16,44 \pm 2,55^{\mathrm{a}}$ & $15,95 \pm 2,58^{\mathrm{a}}$ \\
\hline & $18: 00$ & $17,02 \pm 5,28^{\mathrm{a}}$ & $15,97 \pm 0,80^{\mathrm{a}}$ & $15,90 \pm 1,94^{\mathrm{a}}$ & $16,06 \pm 2,01^{\mathrm{a}}$ \\
\hline
\end{tabular}

Keterangan: Huruf superskrip yang berbeda pada baris yang sama untuk setiap parameter menunjukkan perbedaan yang nyata $(\mathrm{P}<0,05)$, RBC: sel darah merah; Hb: haemoglobin; HCT: hematocrit; MCV: volume rata-rata sel darah merah; $\mathrm{MCH}$ : rata-rata sel haemoglobin; MCHC: konsentrasi rata-rata sel haemoglobin; RDWC: konsentrasi variasi ukuran sel darah merah; WBC: sel darah putih. Perlakuan pemberian pakan berupa konsentrat dan silase masingmasing $800 \mathrm{~g} /$ hari (A), $500 \mathrm{~g} / \mathrm{hari}$ (B), $200 \mathrm{~g} / \mathrm{hari}$ (C), dan tanpa pemberian (D).

Tabel 3. Jumlah differensial sel darah putih kambing sapera dara selama penelitian (rerata \pm SD, $\mathrm{n}=4)$

\begin{tabular}{cccccc}
\hline \multirow{2}{*}{$\begin{array}{c}\text { Waktu } \\
\text { Parameter }\end{array}$} & \multicolumn{5}{c}{ Kelompok } \\
\cline { 3 - 6 }$\left(\begin{array}{c}\text { pengamatan } \\
\text { (Pukul) }\end{array}\right.$ & $\mathrm{A}$ & $\mathrm{B}$ & $\mathrm{C}$ & $\mathrm{D}$ \\
\hline $\mathrm{LIM}\left(10^{3} / \mu \mathrm{L}\right)$ & $06: 00$ & $8,39 \pm 0,18^{\mathrm{a}}$ & $7,26 \pm 1,39^{\mathrm{a}}$ & $7,41 \pm 1,83^{\mathrm{a}}$ & $7,00 \pm 1,41^{\mathrm{a}}$ \\
& $18: 00$ & $7,62 \pm 2,17^{\mathrm{a}}$ & $7,94 \pm 0,36^{\mathrm{a}}$ & $7,34 \pm 1,23^{\mathrm{a}}$ & $6,65 \pm 1,68^{\mathrm{a}}$ \\
$\mathrm{MON}\left(10^{3} / \mu \mathrm{L}\right)$ & $06: 00$ & $0,15 \pm 0,05^{\mathrm{a}}$ & $0,18 \pm 0,04^{\mathrm{a}}$ & $0,21 \pm 0,09^{\mathrm{a}}$ & $0,13 \pm 0,04^{\mathrm{a}}$ \\
& $18: 00$ & $0,12 \pm 0,03^{\mathrm{a}}$ & $0,21 \pm 0,17^{\mathrm{a}}$ & $0,24 \pm 0,16^{\mathrm{a}}$ & $0,15 \pm 0,03^{\mathrm{a}}$ \\
$\mathrm{NEU}\left(10^{3} / \mu \mathrm{L}\right)$ & $06: 00$ & $9,35 \pm 2,03^{\mathrm{a}}$ & $8,37 \pm 0,75^{\mathrm{a}}$ & $8,82 \pm 1,40^{\mathrm{a}}$ & $8,82 \pm 2,25^{\mathrm{a}}$ \\
& $18: 00$ & $9,28 \pm 3,28^{\mathrm{a}}$ & $7,83 \pm 1,17^{\mathrm{a}}$ & $8,32 \pm 0,80^{\mathrm{a}}$ & $9,27 \pm 2,71^{\mathrm{a}}$ \\
\hline
\end{tabular}

Keterangan: Huruf superskrip yang berbeda pada baris yang sama untuk setiap parameter menunjukkan perbedaan yang nyata $(\mathrm{P}<0,05)$, LIM: limfosit; MON: monosit; NEU: neutrofil. Perlakuan pemberian pakan berupa konsentrat dan silase masing-masing $800 \mathrm{~g} / \mathrm{hari}$ (A), $500 \mathrm{~g} / \mathrm{hari}$ (B), $200 \mathrm{~g} /$ hari (C), dan tanpa pemberian (D).

menunjukkan perbedaan yang nyata $(\mathrm{P}<0,05)$ pada pengamatan pukul 12:00, 14:00, dan 18.00, terutama antara kelompok A dan D. Kelompok D memiliki suhu rektal yang lebih rendah dibandingkan kelompok A. Sama halnya dengan suhu tubuh, suhu rektal yang lebih rendah pada kelompok D dibandingkan dengan kelompok A mungkin disebabkan oleh penurunan aktivitas konsumsi pakan yang menunjukkan kemampuan adaptif kambing D agar tetap dingin pada pagi hari untuk mengatasi suhu lingkungan yang tinggi pada 
siang hari. Hal ini juga kemungkinan karena mekanisme termolabilitas yang mengarah ke penurunan suhu rektal untuk mengatasi keterbatasan air dan pakan (Wooden dan Walsberg, 2002).

Detak jantung secara statistika menunjukkan perbedaan yang nyata $(\mathrm{P}<0,05)$ terutama kambing sapera dara pada kelompok A dan D di semua waktu pengamatan. Detak jantung kambing penelitian berkisar antara 72,0 dan 99,5 kali per menit dengan nilai detak jantung tertinggi pada kelompok A sedangkan terendah pada kelompok D. Dawson et al. (2007) melaporkan bahwa detak jantung kambing masih dalam kisaran normal, yaitu sebesar 7090 kali per menit. Hasil penelitian menunjukkan masih ada kelompok ternak yang memiliki detak jantung melebihi batas normal, terutama pada kelompok A dan B pada pengamatan pukul 08:00-16:00. Peningkatan detak jantung dalam penelitian ini mungkin disebabkan oleh peningkatan aktivitas konsumsi pakan. Hasil ini sejalan dengan penelitian sebelumnya oleh McManus et al. (2009) dan Sejian et al. (2010) pada domba. Peningkatan detak jantung akan meningkatkan aliran darah ke jantung sebagai respons kehilangan panas karena konduksi, konveksi, radiasi, dan difusi air dari kulit (Maurya et al., 2004; Marai et al., 2007; Bernabucci et al., 2010; Gupta et al., 2013; Hooda dan Upadhyay, 2014). Begitu pula Mengistu et al. (2007) yang melaporkan bahwa kambing mempertahankan suhu tubuh normal melalui mekanisme termoregulasi, salah satunya dapat diindikasikan dengan adanya peningkatan detak jantung. Beberapa faktor yang memengaruhi detak jantung adalah ukuran tubuh, spesies, jenis kelamin, umur, kondisi fisik, masa kebuntingan, masa laktasi, dan proses ruminasi (Frandson, 1993). Detak jantung yang rendah pada kelompok D menunjukkan kemampuan adaptif kambing kelompok D untuk tetap tenang dengan mengurangi aktivitas metabolismenya sebagai akibat dari kelompok ternak ini yang tanpa pemberian pakan. Hal ini sejalan dengan beberapa penelitian yang telah melaporkan bahwa adanya korelasi antara detak jantung dengan produksi panas metabolik (Barkai et al., 2002; Popoola et al., 2014).

Frekuensi pernapasan kambing percobaan kelompok D lebih rendah dibandingkan dengan kelompok lainnya sejak dari awal pengamatan (pukul 06.00) sampai dengan akhir pengamatan (pukul 18.00), namun tidak menunjukkan perbedaan yang nyata $(\mathrm{P}>0,05)$. Hasil ini menunjukkan kemampuan adaptif kambing kelompok D, seperti umumnya pada ternak yang mengalami stres panas akibat cuaca ekstrem cenderung menjaga tubuhnya agar tetap berada dalam kondisi normal dengan mengubah aktivitas metabolismenya (Alhaidary, 2004; Marai et al., 2007). Selanjutnya, peningkatan frekuensi pernapasan, terutama pada kelompok A lebih banyak relevansinya dengan proses homeostatik untuk pembuangan panas yang berlebihan serta pemeliharaan suhu tubuh kembali pada kondisi normal, seperti yang dilaporkan oleh Rahardja et al. (2011). Lebih lanjut, Kumar et al. (2011) melaporkan bahwa peningkatan frekuensi pernapasan yang terjadi dapat dikaitkan dengan upaya untuk mempertahankan atau mengembalikan keseimbangan termal. Hal ini menunjukkan kemampuan adaptif kambing sapera dara dengan kondisi pakan dan lingkungan yang ada.

\section{Parameter Hematologis}

Evaluasi hematologi darah berperan dalam memahami hubungan antara karakteristik darah dengan lingkungan (Ovuru dan Ekweozor, 2004) dan dijadikan sebagai indikator untuk mengetahui status fisiologis ternak (Šimpraga et al., 2013). Menurut Aderemi (2020), perubahan dalam parameter hematologi darah digunakan untuk menentukan berbagai status tubuh dan stres akibat lingkungan, nutrisi, maupun patologis. Rataan nilai beberapa parameter hematologis kambing sapera dara selama penelitian disajikan pada Tabel 2. Hasil analisis statistika menunjukkan bahwa tidak ada perbedaan yang nyata $(\mathrm{P}>0.05)$ antar kelompok pada semua parameter hematologis baik pada awal pengamatan (06:00) maupun pada akhir pengamatan (18:00). Hal ini sejalan dengan respons fisiologis yang diperoleh dalam penelitian ini, yaitu penurunan jumlah pakan tidak terlalu memberikan pengaruh pada parameter fisiologis. Kambing sapera dara dapat menjaga suhu tubuh dan suhu rektalnya untuk tetap berada dalam kisaran normal, dan peningkatan suhu tubuh, suhu rektal, dan detak jantung pada waktu tertentu merupakan upaya untuk mempertahankan keseimbangan termal tubuh. Kemampuan adaftif kambing sapera dara terhadap penurunan jumlah pakan hingga tanpa pemberian pakan dalam kondisi lingkungan tertentu tidak menyebabkan perubahan pada nilai hematologis.

Hampir semua nilai hematologis yang 
diperoleh dalam penelitian ini berada dalam kisaran fisiologis kambing (Byers dan Kramer, 2011) dan sesuai dengan hasil penelitian yang dilakukan pada kambing aspromontana, girgentana, messinese, maltese, dan argentata dell'Etna yang berasal dari Italia (Piccione et al., 2014; Arfuso et al., 2016). Jumlah sel darah merah (RBC) dalam penelitian ini adalah sebesar 14,03-15,58 x106/ $\mathrm{L}$, yang hampir sama dengan yang dilaporkan oleh Stevens et al. (1994) pada kambing yang berasal dari pantai North Carolina Amerika Serikat, yaitu sebesar 15,8 $\mathrm{x} 10^{6} / \mu \mathrm{L}$ dan Ribeiro et al. (2016) pada kambing garfagnina dari Brazil, yaitu sebesar 15,5 x106/ $\mu \mathrm{L}$. Laporan sebelumnya pada kambing black bengal asal Bangladesh (Alam et al., 2013), kambing dwarf asal Nigeria (Okoruwa, 2014), dan kambing baladi asal Mesir (El-Tarabany et al., 2017) menunjukkan nilai RBC yang lebih rendah masing-masing sebesar $11,2,5,98$, dan $10,02 \times 10^{6} / \mu \mathrm{L}$.

Kadar haemoglobin $(\mathrm{Hb})$ dalam penelitian ini adalah sebesar 8,73-9,55 g/dL, yang hampir sama dengan yang dilaporkan oleh Opara et al. (2010) pada kambing jantan west african dwarf asal Nigeria, yaitu sebesar 9,5 g/dL dan (ElTarabany et al., 2017) pada kambing baladi asal Mesir, yaitu sebesar 9,46 g/dL. Hasil ini lebih tinggi dari yang dilaporkan oleh Alam et al. (2013) pada kambing black bengal asal Bangladesh dan Okoruwa, (2014) pada kambing dwarf asal Nigeria yang masing-masing sebesar 8,9 dan 6,99 g/dL. Berbeda halnya dari yang dilaporkan oleh Stevens et al. (1994) pada kambing yang berasal dari pantai North Carolina Amerika Serikat dengan nilai $\mathrm{Hb}$ yang lebih tinggi, yaitu sebesar 10,3 g/dL.

Jumlah sel darah putih (WBC) dalam penelitian ini adalah sebesar 15,90-17,89 x10/ $\mu \mathrm{L}$, yang hampir sama dengan yang dilaporkan Opara et al. (2010) pada kambing jantan west african dwarf asal Nigeria, yaitu sebesar 17,3 $\mathrm{x} 10^{3} / \mu \mathrm{L}$. Laporan sebelumnya pada kambing black bengal asal Bangladesh (Alam et al., 2013) dan kambing dwarf asal Nigeria (Okoruwa, 2014) menunjukkan jumlah WBC yang lebih rendah yang masing-masing sebesar 7,6 dan $12,6 \times 10^{3} / \mu \mathrm{L}$.

Jumlah RBC, WBC, dan kadar Hb yang bervariasi berkaitan dengan jenis kambing (Okonkwo et al., 2011; Zumbo et al., 2011), umur (Piccione et al., 2014), status reproduksi, kandang, pakan, faktor lingkungan, stres, dan transportasi ternak (Watson et al., 1994; Waziri et al., 2010). Jumlah RBC dan kadar Hb yang lebih tinggi merupakan mekanisme adaptif untuk menyediakan air yang dibutuhkan selama proses pendinginan evaporatif(Alhaidary, 2004). Lebih lanjut Okonkwo et al. (2011) melaporkan bahwa hewan dengan jumlah RBC dan kadar $\mathrm{Hb}$ yang lebih tinggi memiliki kemampuan adaptasi yang lebih baik karena dapat mengangkut oksigen dalam jumlah besar. Sementara itu, menurut Srikandakumar dan Johnson (2004), penurunan kadar Hb sebagai proses lisis dari RBC bias terjadi karena peningkatan radikal bebas pada membran $\mathrm{RBC}$ yang kaya akan lipid yang disebabkan oleh stres panas atau karena keterbatasan pakan yang tersedia di samping itu, umur ternak memiliki efek yang signifikan pada jumlah WBC untuk semua jenis kambing. Jumlah WBC yang lebih tinggi ditemukan pada kambing dara dibandingkan dengan kambing yang lebih tua (Daramola et al., 2005). Menurut Byers dan Kramer (2010) dan Piccione et al. (2014), kambing dara memiliki sistem perlindungan yang baik sehingga memberikan pertahanan yang cepat dan kuat terhadap agen infeksi.

Jumlah differensial sel darah putih kambing sapera dara selama penelitian disajikan pada Tabel 3. Diferensial sel darah putih, baik jumlah LIM, MON, dan NEU, secara statistika tidak berbeda nyata $(\mathrm{P}>0.05)$ antar kelompok kambing percobaan, sejalan dengan respons fisiologis dan jumlah WBC yang dihasilkan. Hal tersebut menunjukkan kemampuan adaptif kambing sapera dara walaupun terjadi penurunan jumlah pakan hingga tanpa pemberian pakan. Alam et al. (2013) melaporkan bahwa neutrofil (NEU) berperan sebagai pelindung utama tubuh dari infeksi dan antigen, dan jumlah NEU yang tinggi mengindikasikan infeksi aktif, sedangkan nilai yang rendah mengindikasikan sistem kekebalan tubuh yang terganggu. Limfosit (LIM) berperan sebagai perlindung tubuh terhadap infeksi virus, dan nilai limfosit yang tinggi menunjukkan sistem kekebalan tubuh yang sudah menurun. Sementara itu, monosit (MON) sangat membantu dalam melawan infeksi tubuh yang akut dan dianggap sebagai sistem pertahanan terakhir tubuh terhadap infeksi sel pada aliran darah.

\section{SIMPULAN}

Kambing perah sapera dara memiliki kemampuan adaptif terhadap stres panas akibat pembatasan kuantitas pakan, terlihat dengan 
respons fisiologis dan hematologis dari keempat kelompok yang menunjukkan perbedaan hanya di beberapa titik pengamatan. Kambing perah sapera dara mampu mempertahankan atau mengembalikan keseimbangan termal tubuhnya melalui mekanisme termoregulasi dan perbedaan tersebut hanya sebagai bentuk respons adaptif untuk mengurangi aktivitas metabolisme yang terjadi.

\section{SARAN}

Penelitian lebih lanjut diperlukan untuk mengetahui jangka waktu kemampuan adaftif kambing sapera dara terhadap stres akibat pembatasan kuantitas pakan dan efeknya terhadap produksi dan reproduksi kambing.

\section{UCAPAN TERIMA KASIH}

Kami ingin mengucapkan terima kasih kepada Ir. Anneke Anggraeni M.Si., Ph.D. beserta staf teknisi Unit Penelitian Kambing, Balai Penelitian Ternak Ciawi, Bogor, Indonesia atas bantuan teknisnya. Penulis mengucapkan terima kasih atas dukungan keuangan dari Bantuan Biaya Penelitian Petugas Belajar Balitbangtan 2019 dan DIPA Balai Penelitian Ternak Tahun Anggaran 2019 dengan nomor protokol: 1806.201.003.051A/D2/APBN/2019.

\section{DAFTAR PUSTAKA}

Aderemi F. 2020. Effects of replacement of wheat bran with cassava supplemented or unsupplemented with enzyme on the haematology and serum biochemistry of pullet chicks. J Trop Forest Sci 7: 147153.

Alam M, Hashem M, Rahman M, Hossain M, Haque M, Sobhan Z, Islam M. 2013. Effect of Heat Stress on Behavior, Physiological and Blood Parameters of Goat. Prog Agr 22(1-2): 37-45. https://doi.org/10.3329/ pa.v22i1-2.16465

Alhaidary A. 2004. Physiological responses of Naimey Sheep to heat stress challenge under semi-arid environments. Int $J A g r$ Biol 6(2): 307-309.

Arfuso F, Fazio F, Rizzo M, Marafioti S, Zanghì E, Piccione G. 2016. Factors Affecting the
Hematological Parameters in Different Goat Breeds from Italy. Ann Anim Sci 16(3): 743757. https://doi.org/10.1515/aoas-2015-0094

Aryanto, Suwignyo B, Panjono. 2013. Efek pengurangan dan pemenuhan kembali jumlah pakan terhadap konsumsi dan kecernaan bahan pakan pada kambing Kacang dan Peranakan Etawah. Buletin Peternakan 37(1): 12-18.

Ayo JO. 1998. Body temperature, respiration and heart rate in the Red Sokoto goat during the harmattan season. B Anim Health Prod in Africa 46: 161-166. https://ci.nii.ac.jp/ naid/10021224689/en/

Barkai D, Landau S, Brosh A, Baram H, Molle G. 2002. Estimation of energy intake from heart rate and energy expenditure in sheep under confinement or grazing condition. Liv Prod Sci 73(2-3): 237-246. https://doi.org/ 10.1016/S0301-6226(01)00251-2

Bernabucci U, Lacetera N, Baumgard LH, Rhoads RP, Ronchi B, Nardone A. 2010. Metabolic and hormonal acclimation to heat stress in domesticated ruminants. Animal 4(7): 1167-1183. https://doi.org/10.1017/ S175173111000090X

Byers SR, Kramer JW. 2010. Normal hematology of sheep and goat. In: Weiss DJ, Wardrop KJ (Eds). Schalm's Veterinary Hematology. Ames, IA, USA: Blackwell. Pp. 836-842.

Caulfield MP, Cambridge H, Foster SF, McGreevy PD. 2014. Heat stress: A major contributor to poor animal welfare associated with long-haul live export voyages. Vet $J$ 199(2): 223-228. https://doi.org/10.1016/ j.tvjl.2013.09.018

Daramola J, Adeloye A, Fatoba TA, Soladoye AO. 2005. Haematological and biochemical parameters of West African Dwarf goats. Liv Res Rural Dev 17(8): 95.

Daramola JO, Adeloye AA. 2009. Physiological adaptation to the humid tropics with special reference to the West African Dwarf (WAD) goat. Trop Anim Health Prod 41(7): 10051016. https://doi.org/10.1007/s11250-0089267-6

Darcan N, Güney O. 2008. Alleviation of climatic stress of dairy goats in Mediterranean climate. Small Rum Res 74(1-3): 212-215. https://doi.org/10.1016/j.smallrumres. 2007.02.007 
Das R, Sailo L, Verma N, Bharti P, Saikia J, Imtiwati, Kumar R. 2016. Impact of heat stress on health and performance of dairy animals: A review. Vet World 9(3): 260-268. https://doi.org/10.14202/vetworld.2016.260268

Dawson L, Allen J, Olcott B. 2007. Meat Goat Herd Health Procedures and Prevention. Proc $22^{\text {nd }}$ Ann Goat Field Day, Langston University, Langston, OK., 18-44.

El-Tarabany MS, El-Tarabany AA, Atta MA. 2017. Physiological and lactation responses of Egyptian dairy Baladi goats to natural thermal stress under subtropical environmental conditions. Int J Biometeorology 61(1): 61-68. https://doi.org/ 10.1007/s00484-016-1191-2

Frandson RD. 1993. Anatomi dan fisiologi ternak. Gadjah Mada University Press. https://books.google.co.id/books?id= jLOstgAACAAJ

García II, López-Gatius F, Bech-Sabat G, Santolaria P, Yániz JL, Nogareda C, De Rensis F, López-Béjar M. 2007. Climate factors affecting conception rate of high producing dairy cows in northeastern Spain. Theriogenology 67(8): 1379-1385. https:// doi.org/10.1016/j.theriogenology.2007.02.009

Gendelman M, Roth Z. 2012. Seasonal Effect on Germinal Vesicle-Stage Bovine Oocytes Is Further Expressed by Alterations in Transcript Levels in the Developing Embryos Associated with Reduced Developmental Competence1. Biol Reprod 86(1). https://doi.org/10.1095/biolreprod. 111.092882

Gupta M, Kumar S, Dangi S, Jangir B. 2013. Physiological, Biochemical and Molecular Responses to Thermal Stress in Goats. Int $J$ Liv Res 3(2): 27. https://doi.org/10.5455/ ijlr.20130502081121

Hooda OK, Upadhyay RC. 2014. Physiological Responses, Growth Rate and Blood Metabolites Under Feed Restriction and Thermal Exposure in Kids. J Stress Physiol Biochem 10(2): 214-227.

Horowitz M. 2002. From molecular and cellular to integrative heat defense during exposure to chronic heat. Comp. Biochem. Physiol. Part A: Molecular \& Integrative Physiology 131(3): 475-483. https://doi.org/10.1016/ S1095-6433(01)00500-1
Kumar BVS. Kumar A, Kataria M. 2011. Effect of heat stress in tropical livestock and different strategies for its amelioration. $J$ Stress Physiol Biochem 7(1): 45-54.

Lee CN, Keala N. 2005. Evaluation of cooling system to improve lactating Holstein cows comfort in the sub tropics. J Anim Sci 82: 128-136.

Marai IFM, El-Darawany AA, Fadiel A, AbdelHafez MAM. 2007. Physiological traits as affected by heat stress in sheep-A review. Small Rum Res 71(1-3): 1-12. https:// doi.org/10.1016/j.smallrumres.2006.10.003

Maurya VP, Naqvi SMK, Mittal JP. 2004. Effect of dietary energy level on physiological responses and reproductive performance of Malpura sheep in the hot semi-arid regions of India. Small Rum Res 55(1-3): 117-122. https://doi.org/10.1016/j.smallrumres. 2003.12.008

McLean JA, Downie AJ, Jones CDR, Stombaugh DP, Glasbey CA. 1983. Thermal adjustments of steers ( Bos taurus ) to abrupt changes in environmental temperature. $J$ Agr Sci 100(2): 305-314. https://doi.org/ 10.1017/S0021859600033451

McManus C, Paludo GR, Louvandini H, Gugel R, Sasaki LCB, Paiva SR. 2009. Heat tolerance in Brazilian sheep: Physiological and blood parameters. Trop Anim Health Prod 41(1): 95-101. https://doi.org/10.1007/ s11250-008-9162-1

Mengistu U, Dahlborn K, Olsson K. 2007. Effects of intermittent watering on water balance and feed intake in male Ethiopian Somali goats. Small Rum Res 67(1): 45-54. https:/ /doi.org/10.1016/j.smallrumres.2005.09.026

Misra RP, Puneet K. 2009. Improved shelter management, feeding and watering devices for goats. Dalam: Kumar S, Sharma MC, Goel AK (eds). Goat enterprises. Mathura (U.P.), India. CIRG. Hlm. 132.

Montanholi YR. Odongo NE, Swanson KC, Schenkel FS, McBride BW, Miller SP. 2008. Application of infrared thermography as an indicator of heat and methane production and its use in the study of skin temperature in response to physiological events in dairy cattle (Bos taurus). J Therm Biol 33(8): 468-475. https://doi.org/10.1016/ j.jtherbio.2008.09.001 
Mortola JP, Frappell PB. 2000. Ventilatory Responses to Changes in Temperature in Mammals and Other Vertebrates. Ann Rev Physiol 62(1): 847-874. https://doi.org/ 10.1146/annurev.physiol.62.1.847

Naiddin A, Rokhmat MN, Dartosukarno S, Arifin M, Purnomoadi A. 2010. Respon fisiologis dan profil darah sapi Peranakan Ongole (PO) yang diberi pakan ampas teh dalam level yang berbeda. Pros. Seminar Nasional Teknologi Peternakan dan Veteriner, Pusat Penelitian dan Pengembangan Peternakan, Bogor 3-4 Agustus 2010. Hlm. 217-223.

Okonkwo JC, Okonkwo IF, Ebuh GU. 2011. Effect of breed, sex and source within breed on the heamatological parameter of the nigerian goats. Online J Anim Feed Res 1(1): 8-13.

Okoruwa MI. 2014. Effect of heat stress on thermoregulatory, live bodyweight and physiological responses of dwarf goats in southern Nigeria. European Scientif J 10: 255-264. https://doi.org/https://doi.org/ 10.19044/esj.2014.v10n27p\%25p

Opara M, Udevi N, Ifeanyi Charles O. 2010. Hematological parameters and blood chemistry of apparently healthy WAD goats in Owerri, South eastern Nigeria. New York Sci J 3: 68-72.

Otoikhian CSO, Orheruata JA, Imasuen JA, Akporhuarho OP. 2009. Physiological response of local (West African Dwarf) and adapted Switzerland (White Bornu) goat breed to varied climatic conditions in SouthSouth Nigeria. Afri J Gen Agr 5(1): 1-6.

Ovuru, Ekweozor I. 2004. Haematological changes associated with crude oil ingestion in experimental rabbits. Afri J Biotechnol 3: 32-38. https://doi.org/10.5897/ AJB2004.000-2064

Piccione G, Monteverde V, Rizzo M, Vazzana I, Assenza A, Zumbo A, Niutta PP. 2014. Reference intervals of some electrophoretic and haematological parameters in Italian goats: comparison between Girgentana and Aspromontana breeds. J App Anim Res 42(4): 434-439. https://doi.org/10.1080/ 09712119.2013 .875914

Popoola MA, Bolarinwa MO, Yahaya MO, Adebisi GL, Saka AA. 2014. Thermal comfort effects on physiological adaptations and growth performance of West African dwarf goats raised in Nigeria. European Sci J 3: 275-281.

Pragna P, Sejian V, Bagath M, Krishnan G, Archana PR, Soren NM, Beena V, Bhatta R. 2018. Comparative assessment of growth performance of three different indigenous goat breeds exposed to summer heat stress. J Anim Physiol Anim Nutr. 102(4): 825836. https://doi.org/10.1111/jpn.12892

Rahardja DP, Toleng AL, Lestari VS. 2011. Thermoregulation and water balance in fattailed sheep and Kacang goat under sunlight exposure and water restriction in a hot and dry area. Animal 5(10): 1587-1593. https:// doi.org/10.1017/S1751731111000577

Refinetti R. 2010. The circadian rhythm of body temperature. Front Biosci 15(1): 564-594. https://doi.org/10.2741/3634

Ribeiro NL, Costa RG, Pimenta Filho EC, Ribeiro MN, Crovetti A, Saraiva EP, Bozzi R. 2016. Adaptive profile of Garfagnina goat breed assessed through physiological, haematological, biochemical and hormonal parameters. Small Rum Res 144: 236-241. https://doi.org/10.1016/j.smallrumres. 2016.10.001

Sejian V, Bhatta R, Gaughan JB, Dunshea FR, Lacetera N. 2018. Review: Adaptation of animals to heat stress. Animal 12(s2): s431s444. https://doi.org/10.1017/S17517311 18001945

Sejian V, Maurya VP, Naqvi SMK. 2010. Adaptability and growth of Malpura ewes subjected to thermal and nutritional stress. Trop Anim Health Prod 42(8): 1763-1770. https://doi.org/10.1007/s11250-010-9633-z

Shilja S, Sejian V, Bagath M, Mech A, David CG, Kurien EK, Varma G, Bhatta R. 2016. Adaptive capability as indicated by behavioral and physiological responses, plasma HSP70 level, and PBMC HSP70 mRNA expression in Osmanabadi goats subjected to combined (heat and nutritional) stressors. Int J Biometeorol 60(9): 13111323. https://doi.org/10.1007/s00484-0151124-5

Silanikove N, Koluman N. 2015. Impact of climate change on the dairy industry in temperate zones: Predications on the overall 
negative impact and on the positive role of dairy goats in adaptation to earth warming. Small Rum Res 123(1): 27-34. https:// doi.org/10.1016/j.smallrumres.2014.11.005

Silva CF, Sartorelli ES, Castilho ACS, Satrapa RA, Puelker RZ, Razza EM, Ticianelli JS, Eduardo HP, Loureiro B, Barros CM. 2013. Effects of heat stress on development, quality and survival of Bos indicus and Bos taurus embryos produced in vitro. Theriogenology 79(2): 351-357. https:// doi.org/10.1016/j.theriogenology.2012.10.003

Šimpraga M, Šmuc T, Matanoviæ K, Radin L, Shek-Vugroveèki A, Ljubièiæ I, Vojta A. 2013. Reference intervals for organically raised sheep: Effects of breed, location and season on hematological and biochemical parameters. Small Rum Res 112(1-3): 1-6. https://doi.org/10.1016/j.smallrumres. 2012.11.032

Srikandakumar A, Johnson EH. 2004. Effect of Heat Stress on Milk Production, Rectal Temperature, Respiratory Rate and Blood Chemistry in Holstein, Jersey and Australian Milking Zebu Cows. Trop Anim Health Prod 36(7): 685-692. https://doi.org/ 10.1023/B:TROP.0000042868.76914.a9

Stevens JB, Anderson KL, Correa MT, Stewart T, Braselton WE. 1994. Hematologic, Blood Gas, Blood Chemistry, and Serum Mineral Values for a Sample of Clinically Healthy Adult Goats. Vet Clin Pathol 23(1): 19-24. https://doi.org/10.1111/j. 1939 165X.1994.tb01011.x

Watson DL, Colditz IG, Andrew M, Gill HS, Altmann KG. 1994. Age-dependent immune response in Merino sheep. Res Vet Sci 57(2): 152-158. https://doi.org/10.1016/00345288(94)90051-5
Waziri M, Ribad AY, Sivachelvan N. 2010. Changes in the serum proteins, hematological and some serum biochemical profifi les in the gestation period in the Sahel goats. Vet Arhiv 80: 215-224.

Widyarti M, Oktavia Y. 2011. Analisis Iklim Mikro Kandang Domba Garut Sistem Tertutup Milik Fakultas Peternakan IPB. JTEP Jurnal Keteknikan Pertanian 25(1): 37-42.

Wolfenson D, Roth Z, Meidan R. 2000. Impaired reproduction in heat-stressed cattle: basic and applied aspects. Anim Reprod Sci 6061: 535-547. https://doi.org/10.1016/S03784320(00)00102-0

Wooden KM, Walsberg GE. 2002. Effect of environmental temperature on body temperature and metabolic heat production in a heterothermic rodent, Spermophilus tereticaudus. J Exp Biol 205(Pt 14): 2099_ 2105.

Yani A, Suhardiyanto H, Hasbullah R, Purwanto BP. 2007. Analisis dan Simulasi Distribusi Suhu Udara pada Kandang Sapi Perah Menggunakan Computational Fluid Dynamics (CFD). Media Peternakan 30(3): 218-228.

Zumbo A, Sciano S, Messina V, Casella S, Di Rosa A, Piccione G. 2011. Haematological profile of messinese goat kids and their dams during the first month post-partum. Anim Sci Pap R 29: 223-230. 